\section{Internationalization via "Europeanization": The Dimension in Spain}

\section{LAURA E. RUMBLeY}

Laura E. Rumbley is a research associate at the Boston College Center for International Higher Education. E-mail: rumbley@bc.edu.

Tn a 200 I article in Higher Education in Europe, Martha Peach Inoted that Spain's entrance into the European Union (EU) in I986 "breached the walls surrounding education and introduced educational internationalization." Since that time, internationalization has emerged as a dynamic element in Spanish higher education, with the European dimension of this effort standing out as a factor affecting the pace and shape of the phenomenon. Indeed, Spanish adhesion to the EU two decades ago set into motion a unique set of opportunities and imperatives to advance the international dimension in the universities of Spain. While much has been accomplished, more remains to be done if Spain wishes to enhance the benefits created by the momentum of Europeanization.

\section{The Legal Framework}

The most recent iteration of the country's higher education law clearly reveals the influence of international developments on the higher education system in Spain. Approved in March 2007, this new national legislation seeks to correct "deficiencies" in existing higher education law and to improve the quality of Spanish universities as a direct result of developments over the last several years in cooperative higher education policy in Europe. It even endorses a long overdue initiative to establish a formal public entity to promote the Spanish university system internationally. In doing so, the law represents the latest installment in a growing body of evidence that Europeanization has deeply infiltrated the legal framework and public policy debate around higher education in Spain.

\section{Institutional and Systemic Changes}

The effects of Spanish engagement with Europe over the last 20 years are difficult to miss. Following decades of isolation under the repressive regime of Francisco Franco, Spain charged enthusiastically into its EU membership in the midI980 and immediately began to take advantage of the mechanisms provided by the EU to advance the international dimension of Spanish higher education. The most dramatic example of this behavior can be seen in the Spanish involvement with ERASMUS, the flagship European student mobility program. From a modest initial Spanish cohort of just 240 students in the program's inaugural year (I987/88), Spain now sends around 2I,000 participants abroad annually through ERASMUS programming. Spain has also become the most popular ERASMUS destination country since 2002/03, hosting more than 25,500 students in 2004/05.

Spain's engagement with ERASMUS has produced significant results far beyond the context of this specific program. Across the board, the universities in Spain since the midI980s have developed new offices to serve international students and scholars, as well as other dimensions of an expanding international agenda. An increasingly professionalized cadre of university staff and administrators has emerged to service the growing international populations in Spain, and to meet the expanding international needs of domestic constituents. Many universities have drafted new policies to develop more systematically the international dimensions of these institutions, which now find themselves formally linked through cooperative agreements with a large number of peer institutions across the continent of Europe and beyond.

\section{Spain has also become the most popular ERAS-}

MUS destination country since 2002/03, hosting more than 25,500 students in 2004/05.

Meanwhile, the Spanish commitment to the Bologna Process is moving Spain's interest in Europe and its Europeanization strategy to new levels. The country has made significant progress in implementing the European Credit Transfer System and the degree-supplement initiative, as well as strengthening its evaluation and quality assurance activities through the creation of a national agency for quality assurance and accreditation (known as its Spanish acronym, ANECA).

These developments have served to transform the basic operational function of Spanish universities as well as the manner in which they reflect on their broader roles and missions. The growing number of international students on Spanish university campuses have precipitated real adjustments in administrative structures, procedures, and mindsets, in order to respond more effectively to changing student, faculty, and institutional needs. On a grander scale, the mainstreaming of international academic engagement-be it through student and scholarly exchange, joint research activities, or increasingly internationalized curricula and pedagogical approaches - has pervaded much of the Spanish university community. These trends mark a major sea change from the more parochial character of Spanish universities just a generation ago.

\section{Looking Beyond Europe}

As European internationalization has solidified in recent years, the universities in Spain have found themselves better positioned and increasingly motivated to develop connections in 
other parts of the world. Historical, cultural, and linguistic linkages with Latin America have made that region an obvious target for Spanish university activity abroad. A wide range of Spanish initiatives in Latin America-at the national, institutional, and even individual levels - have placed the country at the forefront of European activity in the region. Spain is also keen to play a leadership role in the evolving plans for an IberoAmerican higher education space and a Latin American, Caribbean, and European Union education space. Though much more limited in scope, engagement with the United States is also an extremely important focal point for Spanish internationalization. Meanwhile, Spain seeks to play off its historical ties with North Africa to cultivate partners there and in the Middle East and is now turning an eye to the emerging economic and higher education sectors of China and India.

\section{Consolidating Gains}

Despite the more global dimensions of internationalization, Europeanization has unquestionably driven and shaped much of the Spanish approach to the phenomenon over the last 20 years. In the EU, the opportunities and imperatives to internationalize have provided enormous benefits for the universities of Spain-including the confidence, know-how, and organizational capacity to craft a dynamic international dimension. These institutions now face the challenge to find the will, expertise, and resources to assess what has been accomplished and to determine where to go from here.

The universities in Spain, as elsewhere, are operating in a highly competitive environment. Strategic planning for inter-

\section{As European internationalization has solidified in} recent years, the universities in Spain have found themselves better positioned and increasingly motivated to develop connections in other parts of the world.

nationalization must meet the need to advance international agendas that are comprehensive, relevant, and of high quality. The demands of internationalization are changing, and the potential rewards are considerable. The phenomenon is understood as both a means for institutional advancement and a fundamental end in itself for any vibrant higher education institution. The universities of Spain must therefore move forward with creative visions that turn on purposeful, sustainable plans for achieving their internationalization goals-European or otherwise.

\section{From the Private to the Public Governance of Universities: Britain and Europe}

\author{
Michael Shattock
}

Michael Shattock is visiting professor of higher education at the Institute of Education, University of London. He previously served as the registrar at the University of Warwick. E-mail: shattock@he.u-net.com.

$\mathrm{T}^{\mathrm{t}}$ is a paradox of British higher education that in the period 1 between I946 and I980 when British universities received between 80 and 90 percent of their funding from the state they enjoyed the most freedom from state control. But in the period 1980-2006 when nonstate income rose to an average of over 40 percent of institutional income, with many research-intensive universities moving to over 70 percent, state intervention in policies directly affecting higher education have greatly intensified.

In the earlier period the University Grants Committee, a body made up almost entirely of academics, acted as a kind of collective minister to protect universities from direct intervention and to mediate the needs of the state with the needs of universities. An "insider" and a senior member of the Funding Council staff has described a fundamental shift in state-university relations over the second period: while it was once the role of the state to provide for the purposes of the universities, it is now the role of the universities to provide for the purposes of the state. We should not be surprised that the state is more interested in higher education. Since I980 the participation rate has risen from 14 percent to over 40 percent of the age group, making higher education the natural presumption for the middle classes; the costs of higher education have escalated (even though unit costs have halved); the importance of higher education to the national knowledge economy is now fully recognized; and the globalization of higher education and particularly the attraction of British universities to international students are seen to be a national asset. Britain is not alone in recognizing the utility of higher education for state purposes, but in Blairite Britain the seepage of policy initiative away from the main functional ministries to the Cabinet Office and the Treasury and the weakness of the collective organizations representing higher education (most notably Universities UK) have led to the increasing dominance of "one size fits all" policies, conceived centrally in government.

The need to reform the public services has been a major preoccupation of the Blair government and its predecessors right back to the original Thatcher revolution. A range of concepts have evolved out of these attempts - the introduction of quasi markets, increasing personal choice, raising quality but 